\title{
PENGARUH PENERAPAN PRINSIP-PRINSIP GOOD CORPORATE GOVERNANCE DAN BUDAYA TRI HITA KARANA TERHADAP KINERJA MANAJERIAL LEMBAGA PERKREDITAN DESA (LPD) PAKRAMAN PADANGSAMBIAN
}

\author{
aNi Made Mery Yandani, bl Gusti Ngurah Putra Suryanata \\ ${ }^{a, b}$ Fakultas Ekonomi dan Bisnis, Universitas Pendidikan Nasional (Undiknas) Denpasar

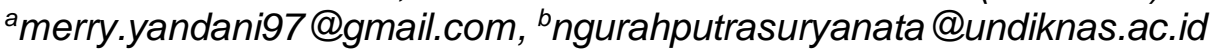

\begin{abstract}
The Influence of Implementation of Good Corporate Governance Principles and Tri Hita Karana Value on Managerial Performance of Village Micro Credit (LPD) at Padangsambian. The current study aims to investigate the influence of transparency, accountability, responsibility, independence, fairness, and THK value on LPD financial performance. Saturated sampling technique were used in the current study, and number of sample used were 30 . The data were collected using primary data through the method of survey. The current study used classic assumption test and multiple linear regression test as an analysis technique. Generally, it could be stated that if Good Corporate Governance $\left(X_{1}\right)$ and The Value of Tri Hita Karana $\left(X_{2}\right)$ increase by one unit (one score), it could has a positive influence towards the managerial performance ( $Y$ ) of LPD Pakraman Padangsambian. This shows that if Good Corporate Governance $\left(X_{1}\right)$ and The value of Tri Hita Karana $\left(X_{2}\right)$ are increased, then the performance of individual managerial $(Y)$ will increase. Otherwise, if Good Corporate Governance $\left(X_{1}\right)$ and the value of Tri Hita Karana $\left(X_{2}\right)$ decrease, there will be a decrease in managerial performance $(Y)$.
\end{abstract}

Keywords: Good corporate governance, Tri Hita Karana value, managerial performance

\section{PENDAHULUAN}

Pembangunan nasional merupakan rangkaian dari pembangunan seluruh aspek yang berkesinambungan. Untuk dapat menunjang pembangunan nasional diperlukan perekonomian yang sehat yang harus dimulai dari tingkatan paling dasar, yaitu tingkat desa. Salah satu lembaga keuangan pedesaan yang dikembangkan terutama di Bali adalah Lembaga Perkreditan Desa (LPD). Pembentukan LPD di Provinsi Bali berawal dari hasil seminar kredit pedesaan yang diselenggarakan di Kota Semarang pada tanggal 20 sampai dengan 21 Februari 1984. Seminar ini menyimpulkan bahwa kehadiran suatu lembaga perkreditan pedesaan dipandang sangat tepat guna menjangkau masyarakat kecil atau miskin di pedesaan sehingga upaya untuk meningkatkan taraf hidup masyarakat golongan tersebut dapat tercapai. Pemilihan desa adat sebagai basis dalam pembentukan LPD di Provinsi Bali adalah dikaitkan dengan usaha untuk melestarikan dan mengembangkan desa adat yang ada di Bali. (Arya Mulyawan dkk, 2017)

LPD memiliki peranan yang sangat strategis bagi masyarakat setempat karena selama ini telah melayani Usaha Mikro Kecil (UMK) dan masyarakat pedesaan melalui pelayanan jasa keuangan yang dilakukan sesuai dengan kebutuhan nasabah, yaitu prosedurnya yang sederhana, tidak berbelit-belit, proses singkat, serta lokasi yang dekat dengan nasabah pedesaan (Yudana dkk., 2015). Peran pengelola LPD sangat menentukan tingkat kesehatan LPD itu sendiri.Pengelolaan LPD yang terpisah dengan krama Desa tidak menutup kemungkinan adanya tindakan mementingkan diri sendiri di pihak pengelola LPD (agent) dan mengabaikan kepentingan krama Desa (principal) yang sering dikenal dengan konflik 
keagenan. Benhart dan Rosenstein (1998) mengatakan bahwa konflik yang timbul karena adanya persinggungan kepentingan antara pemilik dan manajemen dapat berdampak buruk bagi citra perusahaan serta kinerja yang dihasilkan perusahaan tersebut. Menerapkan sistem tata kelola perusahaan yang baik (good corporate governance) juga sangat diperlukan untuk mengurangi terjadinya konflik keagenan. Oliver (1995) mengatakan, corporate governance muncul dalamorganisasi disebabkan karena adanya masalah agensi atau konflik kepentingan yang melibatkan anggota organisasi.

Good Corporate Governance (GCG) merupakan suatu konsep tata kelola perusahaan yang menjelaskan hubungan antara pihak-pihak yang berkepentingan dengan perusahaan dalam upaya perbaikan kinerja perusahaan.Menerapkan sistem tata kelola yang baik pada organisasi sudah didukung dengan dikeluarkannya Pedoman Umum Good Corporate Governance Indonesia oleh Komite Nasional Kebijakan Governance (KNKG) pada tahun 2006. Terdapat unsur penting dalam pedoman tersebut yaitu adanya prinsip-prinsip GCG yang harus diterapkan perusahaan antara lain: transparansi, independensi, akuntabilitas, responsibilitas, dan kewajaran. Menerapkan prinsip-prinsip GCG khususnya pada LPD diharapkan dapat memberikan manfaat pada pengelolaan LPD yang akan mengarah pada kinerja LPD yang lebih baik. Mewujudkan kinerja LPD yang terus maju dan berkembang tidak hanya dipengaruhi oleh sistem tata kelola yang baik, melainkan terdapat faktor lain yang dapat mempengaruhi kinerja LPD adalah budaya organisasi (Gunawan, 2009).

Setiap LPD yang ada di Bali cenderung memiliki budaya organisasi yang berbeda, hal tersebut dikarenakan setiap LPD berada pada wilayah yang berbeda. Perbedaan budaya dalam suatu organisasi secara signifikan akan mempengaruhi kinerja perusahaan (Shu-Mei, 2010). Budaya organisasi dalam penelitian ini mengacu pada budaya lokal masyarakat Bali yaitu Tri Hita Karana (THK). Konsep THK merupakan konsep nilai kultur lokal yang telah tumbuh, berkembang dalam tradisi masyarakat Bali, dan bahkan saat ini telah menjadi landasan falsafah bisnis, filosofi pengembangan pariwisata, pengaturan tata ruang, dan rencana strategik pembangunan daerah (Saputra, 2012). Berdasarkan uraian yang telah dipaparkan, maka penelitian kali ini akan menguji Pengaruh Penerapan Prinsi-prinsip Good Corporate Governance dan Budaya Tri Hita Karana Terhadap Kinerja Manajerial Lembaga Perkreditan Desa (LPD) (Studi pada LPD Pakraman Padangsambian).

Permasalahan yang dapat diangkat dalam penelitian ini yaitu bagaimanakah pengaruh transparansi, akuntabilitas, responsibilitas, independensi, kewajaran dan budaya THK pada kinerja keuangan LPD. Penelitian ini dilakukan dengan tujuan untuk mengetahui pengaruh transparansi, akuntabilitas, responsibilitas, independensi, kewajaran dan budaya THK pada kinerja keuangan LPD. Penelitian ini diharapkan dapat memberikan kegunaan diantaranya kegunaan teoritis yaitu memberikan bukti empiris bahwa teori keagenan yang digunakan dalam penelitian ini dapat menjawab permasalahan yang ada dalam penelitian ini, serta mengenai bagaimana prinsip-prinsip GCG, dan budaya THK mepengaruhi kinerja keuangan LPD.

Konsep Tri Hita Karana (THK) merupakan konsep harmonisasi hubungan yang selalu dijaga masyarakat Hindu Bali meliputi: parahyangan (hubungan manusia dengan Tuhan), pawongan (hubungan manusia dengan sesamanya), dan palemahan (hubungan manusia dengan lingkungan) yang bersumber dari kitab suci agama Hindu Bhagawad Gita. Oleh karena itu, konsep THK yang berkembang di Bali, merupakan konsep budaya yang berakar dari ajaran agama (Riana, 2010 dalam Adiputra, 2014). Konsep harmonisasi hubungan masyarakat Bali pada falsafah Tri Hita Karana diyakini mengandung nilai-nilai sebagai berikut (Gunawan, 2009; Gunawan, 2012) mengatakan yaitu unsur parahyangan, unsur ini mengandung nilai integritas yang terdiri dari bertakwa, penuh dedikasi dan kejujuran. Unsur pawongan, unsur ini mengandung nilai etos kerja, yang terdiri dari kreativitas, bekerja keras dalam bekerja, menghargai waktu, bekerja sama secara harmonis, setia kepada janji, bertindak efisien, dan penuh prakarsa. Unsur palemahan, prinsip ini mengandung nilai kelestarian lingkungan yang terdiri dari membangun, memelihara, dan mengamankan.

Adanya prinsip-prinsip Good Corporate Governance dan Budaya Tri Hita Karana di dalam lingkungan kerja LPD diharapkan mampu menciptakan suasana kerja yang terstruktur, transparan, harmonis dan mengubah pola piker modernisasi dan globalisasi yang 
berdasarkan kepentingan individual, dan materialisme dalam pola piker pegawai LPD dalam melaksanakan fungsi manajerial yang merupakan pilar untuk menunjang kreabilitas dan sinergitas LPD sehingga, dapat terus bertumbuh lebih baik dan memperoleh kepercayaan dalam lingkungan masayarakat Desa Adat.

\section{Rumusan Masalah.}

Dari hasil pemaparan latar belakang maka ditentukan suatu identifikasi pokok permasalahan yaitu sebagai berikut:

1. Apakah Good Corporate Governance berpengaruh positif terhadap kinerja manajerial Lembaga Perkreditan Desa (LPD) Pakraman Padangsambian?

2. Apakah Budaya Tri Hita Karana berpengaruh positif pada kinerja manajerial Lembaga Perkreditan Desa (LPD) Pakraman Padangsambian?

3. Apakah Good Corporate Governance dan Budaya Tri Hita Karana berpengaruh positif terhadap kinerja manajerial Lembaga Perkreditan Desa (LPD) Pakraman Padangsambian?

\section{Tujuan Penelitian}

Adapun tujuan penelitian ini dilakukan yaitu:

1. Untuk mengetahui pengaruh Prinsip Good Corporate Governance terhadap Kinerja Manajerial Lembaga Perkreditan Desa (LPD) Pakraman Padangsambian.

2. Untuk mengetahui pengaruh Budaya Tri Hita Karana terhadap Kinerja Manajerial Lembaga Perkreditan Desa (LPD) Pakraman Padangsambian.

3. Untuk mengetahui mana lebih berpengaruh terhadap Kinerja Manajerial Lembaga Perkreditan Desa (LPD) Pakraman Padangsambian, Prinsip Good Corporate Governance atau Budaya Tri Hita Karana.

\section{KAJIAN LITERATUR}

\section{Good Corporate Governance}

Tata kelola perusahaan yang baik (Good Corporate Governance) diperlukan untuk mendorong terciptanya pasar yang efisien, transparan dan konsisten dengan peraturan perundang-undangan. Siswanto Sutojo dan John Aldiren dalam bukunya Good Corporate Governance (2015) mengatakan bahwa kata Governance diambil dari kata lain, yaitu gubemane yang artinya mengarahkan (directing) dan mengendalikan (control). Dalam ilmu Manjemen Bisnis, kata tersebut diadaptasikan menjadi Corporate Governance dan diartikan sebagai upaya mengarahkan (directing) dan mengendalikan (control) kegiatan organisasi, termasuk perusahaan. Sedangkan menurut (Zarkasyi: 2008), Good Corporate Governance merupakan suatu sistem (input, process, output) dan seperangkat peraturan yang mengatur hubungan antara berbagai pihak yang berkepentingan (stakeholder) terutama dalam arti sempit hubungan antara pemegang saham, dewan komisaris, dan dewan direksi demi tercapainya tujuan perusahaan.

Berikut ini merupakan penjelasan prinsip-prinsip GCG (Good Corporate Governance) menurut buku pedoman KNKG (Komite Nasional Kebijakan Governance: 2006):

1. Transparansi (Transparency)

Untuk menjaga obyektivitas dalam menjalankan bisnis, perusahaan harus menyediakan informasi yang material dan relevan dengan carayang mudah diakses dan dipahami oleh pemangku kepentingan.

2. Akuntabilitas (Accountability)

Perusahaan harus dapat mempertanggungjawabkan kinerjanya secara transparan dan wajar. Untuk itu perusahaan harus dikelola secara benar, terukur dan sesuai dengan kepentingan perusahaan dengan tetap memperhitungkan kepentingan pemegang saham dan pemangku kepentingan lain.

3. Responsibilitas (Responsibility)

Perusahaan harus mematuhi peraturan perundang-undangan serta melaksanakan tanggung jawab terhadap masyarakat dan lingkungan sehingga dapat terpelihara 
kesinambungan usaha dalam jangka panjang dan mendapat pengakuan sebagai good corporate citizen.

4. Independensi (Independency)

Untuk melancarkan pelaksanaan asas GCG, perusahaan harus dikelola secara independen sehingga masing-masing organ perusahaan tidak saling mendominasi dan tidak dapat diintervensi oleh pihak lain.

5. Kewajaran dan Kesetaraan (Fairness)

Dalam melaksanakan kegiatannya, perusahaan harus senantiasa memperhatikan kepentingan pemegang saham dan pemangku kepentingan lainnya berdasarkan asas kewajaran dan kesetaraan.

\section{Pengertian Budaya Tri Hita Karana}

Tri Hita Karana terdiri atas tiga kata yaitu tri, artinya, tiga, hita artinya, kebahagiaan atau kesejahteraan dan karana artinya, sebab. Jadi Tri Hita Karana (THK) berarti tiga komponen atau unsur yang menyebabkan kesejahtraan atau kebahagiaan.Ketiga komponen THK itu berkaitan erat antara yang satu dengan yang lainnya. Ketiga komponen THK itu meliputi hubungan yang harmonis antara manusia dengan Tuhan Yang Maha Esa (Parhyangan), hubungan yang harmonis antara manusia dengan manusia (Pawongan), dan hubungan yang harmonis antara manusia dengan alam lingkungan (Palemahan). (Sudarta, 2008 : 84). Oleh karenanya, dalam penelitian ini dikaji tentang lingkungan yang berlandaskan THK. Diharapkan dengan diterapkannya THK dalam pengelolaan LPD, maka harmoni dan juga kebersamaan dalam lingkungan LPD akan dapat dicapai, disamping harmoni dan kebersamaan pihak LPD dengan lingkungan sekitarnya. Diyakini bahwa dengan harmonisnya di internal LPD dan antara LPD dengan pihak eksternalnya, maka LPD itu akan menjadi tenang dan damai, serta penuh dengan keharmonisan dan juga kebersamaan.

\section{Pengertian Kinerja Manajerial}

Pengertian kinerja manajerial adalah hasil dari proses aktivitas manajerial yang efektif mulai dari proses perencanaan, pelaksanaan, penatausahaan, laporan pertanggungjawaban, pembinaan, dan pengawasan. Variabel kinerja manajerial diukur dengan menggunakan instrumen self rating yang dikembangkan oleh Mahoney (1963) dalam Alfar (2006), di mana setiap responden diminta untuk mengukur kinerja sendiri ke dalam delapan dimensi, yaitu perencanaan, investigasi, pengkoordinasian, evaluasi, pengawasan, pemilihan staf, negosiasi, dan perwakilan, serta satu dimensi pengukuran kinerja seorang kepala dinas, kepala bagian dan kepala bidang secara keseluruhan.

\section{Lembaga Perkreditan Desa (LPD)}

LPD didirikan oleh Gubernur Ida Bagus Mantra pada tahun 1985, sebagai lembaga keuangan pedesaan berbasis desa adat, yang memeliki peran ekonomi dan sosial di komuniras tersebut (Sutoro, 2015:161). LPD dbentuk berdasarkan Keputusan Gubernur Bali Nomor 972 Tahun 1984 tentang Pembentukan Lembaga Pemerintahan Daerah.

Menurut Peraturan Daerah Provinsi Bali No. 8 Tahun 2002, LPD adalah usaha keuangan milik desa yang melaksanakan kegiatan usaha dilingkungan desa dan untuk krama desa. LPD merupakan lembaga keuangan milik desa pakraman. LPD juga dinyatakan sebagai wadah asset desa adat yang dimiliki oleh warga adat (Eka Damayanthi, 2015:10). Awalnya LPD diatur dalam Peraturan Pemerintah Daerah Bali No. 2 Tahun 1988, namun kemudian dilakukan perubahan hingga pembentukan Peraturan Pemerintah Daerah Bali No. 11 Tahun 2013 tentang LPD (Anantawikrama, 2013). 


\section{Kerangka Pemikiran}

\section{PENGARUH PENERAPAN PRINSIP-PRINSIP GOOD CORPORATE GOVERNANCE DAN BUDA YA TRI HITA KARANA TERHADAP KINERJA MANAJERIAL LEMBAGA PERKREDITAN DESA (LPD) PAKRAMAN PADANGSAMBIAN}

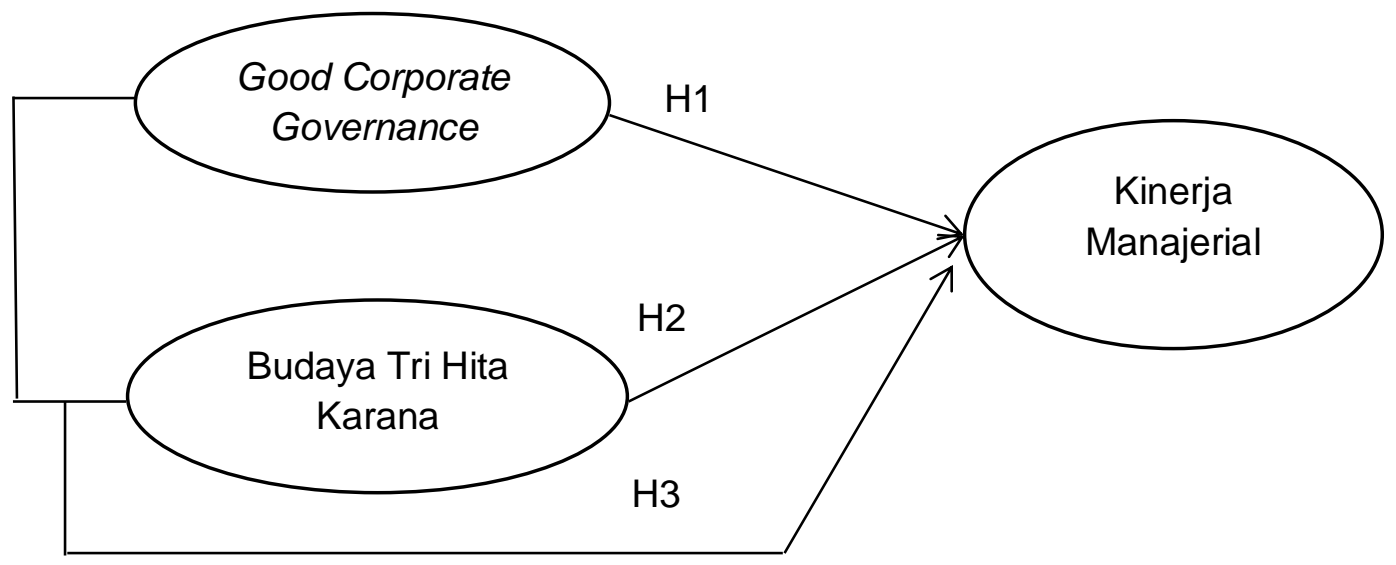

Gambar 1. Kerangka Pemikiran

Kerangka konseptual diatas dapat dijelaskan bahwa Good Corporate Governance (X1), Budaya Tri Hita Karana (X2), mempengaruhi kinerja Manajerial (Y). Kerangka konseptual penelitian dalam gambar diatas menjelaskan bahwa Prinsip-prinsip Penerapan Good Corporate Governance dan Budaya Tri Hita Karana memberikan pengaruh terhadap Kinerja Manajerial. Dengan menerapkan Prinsip-prinsip Good Corporate Governance dan Budaya Tri Hita Karana mampu menciptakan suasana kerja yang terstruktur, transparan, harmonis dan mengubah pola piker modernisasi dan globalisasi yang berdasarkan kepentingan individual, dan materialism dalam pola piker pegawai LPD sehingga Kinerja Manajerial menjadi lebih baik.

\section{Hipotesis Penelitian}

Berdasarkan kerangka penelitian diatas, maka hipotesis yang diajukan dalam penelitian ini yaitu:

$\mathrm{H} 1$ : Good Corporate Governance $\left(\mathrm{X}_{1}\right)$ berpengaruh terhadap kinerja manajerial $(\mathrm{Y})$

$\mathrm{H}$ 2: Budaya Tri Hita Karana $\left(\mathrm{X}_{2}\right)$ berpengaruh terhadap kinerja manajerial $(\mathrm{Y})$

H3: Good Corporate Governance $\left(X_{1}\right)$ dan Budaya Tri Hita Karana $\left(X_{2}\right)$ berpengaruh terhadap kinerja manajerial $(\mathrm{Y})$

\section{Definisi Operasional}

Variabel penelitian merupakan sesuatu yang ditetapkan oleh peneliti untuk dipelajari agar memperoleh informasi yang diperlukan sehingga dapat ditarik kesimpulan. Dalam penelitian ini meliputi variabel bebas dan variabel terikat.

\section{Good Corporate Governance $\left(X_{1}\right)$}

Tata kelola yang dilakukan oleh Lembaga Perkreditan Desa (LPD) yang menjelaskan hubungan antara pihak-pihak yang berkepentingan dengan perusahaan dalam upaya perbaikan kinerja perusahaan.

Adapun indokator-indikatornya yaitu:

1. Transparansi.

LPD telah mencatat dan melaporkan semua transaksi keuangan berdasarkan Prinsip Akuntansi yang Berlaku Umum (PABU).

2. Akuntabilitas. 
Pengawas Internal LPD mampu memberikan kepastian mengenai kebenaran informasi keuangan dan tidak mengalami masalah dengan pihak lain dalam menjalankan tugasnya.

3. Responsibilitas.

Standar Profesional Etika telah diterapkan dalam LPD secara konsisten dan diberi saksi kepada yang melanggar.

4. Independensi.

Membuat kebijakan intern perusahaan yang sesuai dengan hokum dan peraturan yang berlaku.

5. Kewajaran dan Kesetaraan.

Visi, Misi, dan Tujuan LPD telah dipahami oleh seluruh karyawan.

\section{Budaya Tri Hita Karana $\left(\mathbf{X}_{2}\right)$}

Suatu ajaran berdasarkan konsep Hindu yang diterapkan di Lembaga Perkreditan Desa (LPD) Pakraman Padangsambian. Adapun indikator-indikatornya yaitu ;

1. Aspek Parahyangan: Hubungan Manusia dengan Tuhan. Seperti, berdoa sebelum dan sesudah melakukan pekerjaan, berdoa sebelum berangkat kerja dan pemberian pelayanan berdasarkan hati nurani dan tulus iklas.

2. Aspek Pawongan: Hubungan Manusia dengan Manusia. Seperti, berkomunikasi dengan baik, bekerjasama secara harmonis dengan rekan kerja, bersikap ramah terhadap nasabah.

3. Aspek Palemahan: Hubungan Manusia dengan lingkungan. Seperti, lingkungan kerja yang bersih dan nyaman.

Kinerja Manajerial Lembaga Perkreditan Desa (LPD) (Y)

Pengertian kinerja manajerial adalah hasil dari proses aktivitas manajerial yang dilaksanakan secara efektif mulai dari proses perencanaan, pelaksanaan, penatausahaan, laporan pertanggungjawaban, pembinaan, dan pengawasan.

\section{METODE}

\section{Lokasi Penelitian}

Penelitian ini akan dilakukan di LPD Desa Pakraman Padangsambian. Yang berlokasi di Jalan Gunung Sanghyang, Padangsambian Kaja, Denpasar Barat.Di LPD ini lah masyarakat padangsambian menabung uang mereka, dan banyak juga debitur yang melakukan kredit di LPD Pakraman Padangsambian. Populasi dalam penelitian ini yaitu seluruh karyawan LPD Pakraman Padangsambian dengan menggunakan sampel teknik sampling jenuh yaitu teknik penentuan sampel bila semua anggota populasi digunakan sebagai sampel. Jenis data menggunakan data kuantitatif, data Kuantitatif dalam penelitian ini yaitu hasil dari kuisioner yang sesuai dengan indikator yang telah dirumuskan dan mengacu pada pengukuran variable dengan bantuan skala likert. Data yang diperoleh berupa jawaban dari responden yang menggunakan teknik analisis data regresi linier berganda dengan bantuam software SPSS.

\section{HASIL DAN PEMBAHASAN}

\section{Hasil Uji Asumsi Klasik \\ Uji Normalitas}

Model persamaan yang baik adalah distribusi data normal atau mendekati normal, kreteria yang digunakan (Singgih Santoso, 2000:214) adalah sebagai berikut : Jika data menyebar disekitar garis diagonal dan mengikuti arah garis diagonal, maka model persamaan tersebut memenuhi asumsi normalitas. Jika data menyebar jauh dari garis diagonal dan atau tidak mengikuti arah garis diagonal, maka model regresi tersebut tidak memenuhi Asumsi Normalitas. 


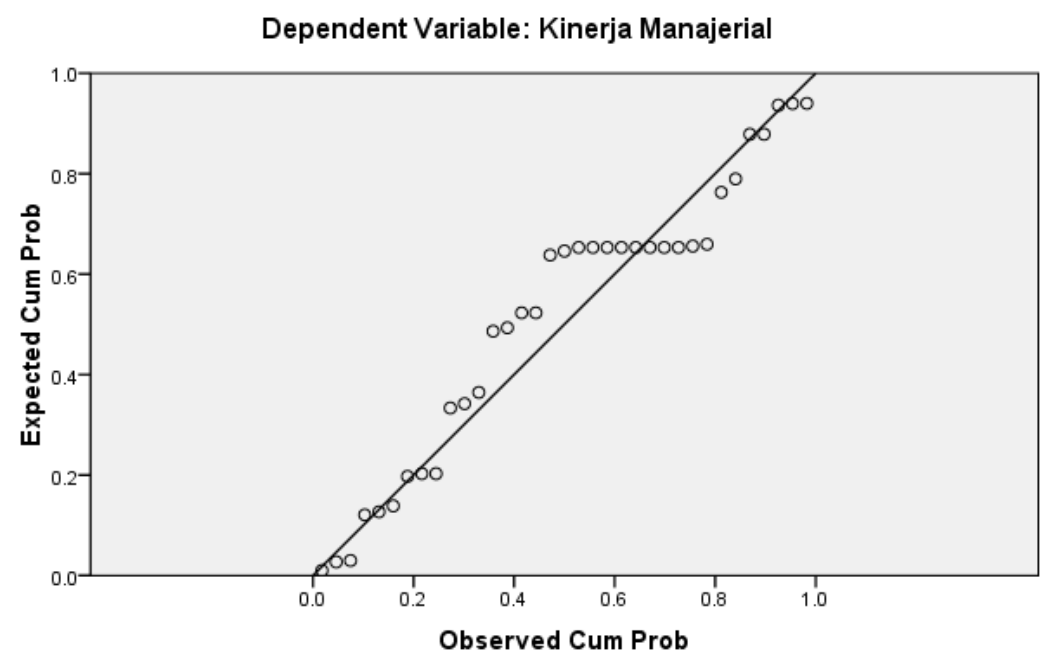

Pada gambar 4 terlihat titik - titik menyebar disekitar garis diagonal, serta penyebarannya mengikuti arah garis diagonal. Dengan demikian dapat dikatakan model regresi sebagaimana dibahas di depan telah memenuhi asumsi normalitas, dan layak dipakai untuk memprediksi variabel terikatnya

\section{Uji Multikolinieritas}

Pengujian ini bertujuan untuk menguji apakah model regresi ditemukan adanya kolerasi antar variabel independen. Untuk menguji multikolinearitas dengan cara melihat nilai VIF masingmasing variabel independen, jika nilai VIF $<10$ maka dapat disimpulkan data bebas dari gejala multikolinearitas (Ghozali : 2011). Adapun nilai VIF dan Tolerance seperti tabel berikut ini.

TABEL 1

\section{Coefficients ${ }^{\Xi}$}

\begin{tabular}{|ll|r|c|}
\hline \multirow{2}{*}{ Model } & \multicolumn{2}{|c|}{ Collinearity Statistics } \\
\cline { 2 - 4 } & Golerance & \multicolumn{1}{c|}{ V|F } \\
\hline 1 & Good Corporate & .634 & 1.577 \\
& Governance & .634 & 1.577 \\
\hline & Budaya Tri Hita Karana & .634 \\
\hline
\end{tabular}

a. Dependent Variable: Kinerja Manajerial

Berdasarkan tabel di atas bahwa dapat diketahui nilai VIP sebesar 1,577 untuk variabel good corporate governance dan varibel budaya tri hita karana. Mengingat nilai VIF $<10$ maka dapat dinyatakan bebas multikolonieritas.

\section{Uji Heteroskedasitas}

Uji heteroskedastisitas dilakukan untuk mengetahui apakah dalam model regresi terjadi ketidaksamaan varians dari residual suatu pengamatan ke pengamatan lain.

Deteksi adanya heteroskedastisitas adalah dengan melihat ada tidaknya pola tertentu dari grafik heteroskedastisitas, dimana sumber $\mathrm{x}$ adalah yang diprediksi dan sumbu y adalah residual yang telah di standarized. Dasar pengambilan keputusan adalah jika titik-titik yang ada membentuk pola tertentu yang teratur maka telah terjadi heteroskedastisitas. Jika tidak 
ada pola yang jelas, serta titik-titik menyebar di atas dan di bawah angka 0 pada sumbu $\mathrm{Y}$, maka tidak terjadi heteroskedasitisitas.

Scatterplot

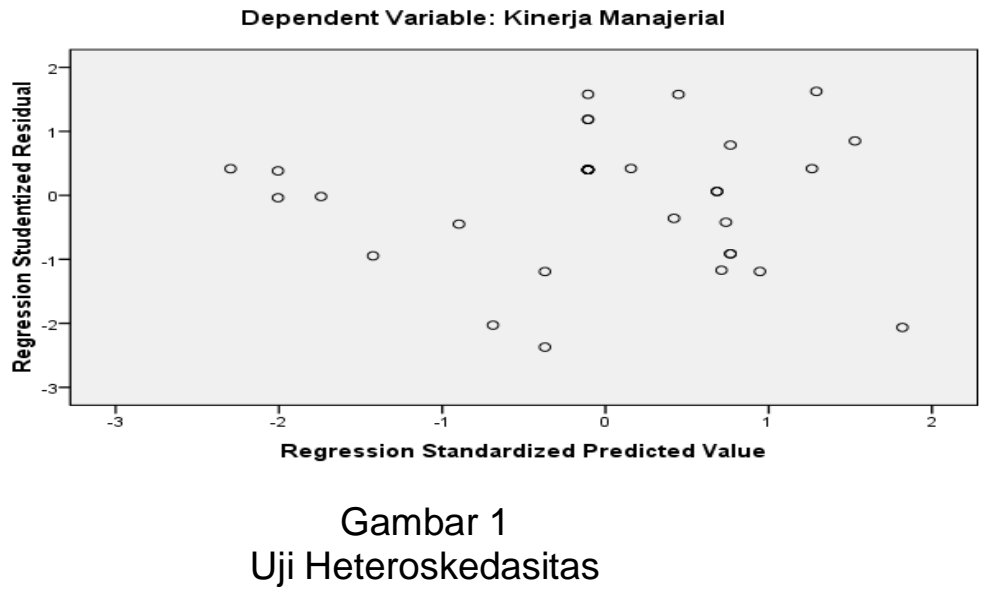

Berdasarkan gambar 1 terlihat titik - titik menyebar secara acak, di atas maupun dibawah angka 0 (nol) pada sumbu $Y$, hal ini berarti tidak terjadi heteroskedastisitas pada model persamaan struktural, sehingga layak dan meyakinkan untuk digunakan memprediksi besarnya variabel devenden berdasarkan masukan variabel indevenden

\section{Hasil Uji Analisis Regresi Linier Berganda}

Analisis persamaan regresi linier berganda ini digunakan untuk mengetahui pola pengaruh variabel bebas Good Corporate Governance $\left(\mathrm{X}_{1}\right)$ dan Budaya Tri Hita Karana $\left(\mathrm{X}_{2}\right)$, terhadap variable terikat kinerja Manajerial (Y) Lembaga Perkreditan Desa (LPD) Pakraman Padangsambian, dengan persamaan umum :

$\mathrm{Y}=\mathrm{a}+\mathrm{b}_{1} \mathrm{X}_{1}+\mathrm{b}_{2} \mathrm{X}_{2}$

Dalam penelitian ini:

$\begin{array}{ll}\mathrm{Y} & =\text { Variabel terikat : Kinerja Manajerial } \\ \mathrm{a} & =\text { Bilangan konstan } \\ \mathrm{b}_{1} \mathrm{~b}_{2} & =\text { Koefisien regresi untuk } \mathrm{X} \\ \mathrm{X}_{1} & =\text { Variabel bebas : Good Corporate Governance } \\ \mathrm{X}_{2} & =\text { Variabel bebas : Budaya Tri Hita Karana }\end{array}$

Dari hasil perhitungan pada Lampiran 5, dapat disajikan Tabel 2 berikut yang memuat konstanta dan koefisien regresi.

TABEL 2

Analisis Regresi Linier Berganda

\begin{tabular}{|c|c|c|c|c|c|c|}
\hline \multicolumn{7}{|c|}{ Coefficients $^{\Xi}$} \\
\hline & & \multicolumn{2}{|c|}{ Unstandardized Coefficients } & $\begin{array}{l}\text { Standardized } \\
\text { Coefficients }\end{array}$ & \multirow[b]{2}{*}{$t$} & \multirow[b]{2}{*}{ Sig. } \\
\hline \multicolumn{2}{|c|}{ Model } & $\mathrm{B}$ & Std. Error & Beta & & \\
\hline \multirow[t]{3}{*}{1} & (Constant) & -.818 & 3.978 & & -.206 & .838 \\
\hline & $\begin{array}{l}\text { Good Corporate } \\
\text { Governance }\end{array}$ & .956 & .220 & .547 & 4.340 & .000 \\
\hline & Budaya Tri Hita Karana & 1.056 & .363 & .367 & 2.908 & .007 \\
\hline
\end{tabular}

a. Dependent Variable: Kinerja Manajerial 
Dari Tabel 2 diatas, dapat diketahui nilai konstanta a, koefisien regresi variable Good Corporate Governance (b1), dan Budaya Tri Hita Karana (b2), yaitu sebagai berikut:

$$
\begin{aligned}
& a=-0,818 \\
& b 1=0,956 \\
& b 2=1,056
\end{aligned}
$$

Berdasarkan data diatas, persamaan regresi linier berganda yang menggambarkan pola pengaruh variabel bebas Good Corporate Governance $\left(\mathrm{X}_{1}\right)$ dan Budaya Tri Hita Karana $\left(\mathrm{X}_{2}\right)$, terhadap variable terikat kinerja Manajerial (Y) Lembaga Perkreditan Desa (LPD) Pakraman Padangsambian, dapat dinyatakan sebagai berikut:

$\mathrm{Y}=\mathrm{a}+\mathrm{b} 1 \mathrm{X} 1+\mathrm{b} 2 \mathrm{X} 2$

$Y=-0,818+0,956 X_{1}+1,056 X_{2}$

\section{Uji Analisis Determinasi}

Analisis ini digunakan untuk mengetahui besarnya persentase pengaruh variabel yang diteliti, yaitu antara variabel bebas Good Corporate Governance $\left(\mathrm{X}_{1}\right)$ dan Budaya Tri Hita Karana $\left(\mathrm{X}_{2}\right)$, terhadap variable terikat kinerja Manajerial $(\mathrm{Y})$ Lembaga Perkreditan Desa (LPD) Pakraman Padangsambian. Rumus untuk menentukan besarnya koefisien determinasi (D) adalah $\mathrm{D}=\mathrm{R}^{2} \times 100 \%$.

Dari hasil perhitungan pada Lampiran 5, dapat disajikan Tabel 3 berikut yang memuat koefisien korelasi (R) dan kwadrat koefisien korelasi (R-square).

\section{Model Summary}

\begin{tabular}{|l|l|r|r|r|r|}
\hline Mode & $\mathrm{R}$ & $\mathrm{R}$ Square & $\begin{array}{c}\text { Adjusted R } \\
\text { Square }\end{array}$ & $\begin{array}{c}\text { Std. Error of } \\
\text { the Estimate }\end{array}$ & $\begin{array}{c}\text { Durbin- } \\
\text { Watson }\end{array}$ \\
\hline 1 & $.823^{\mathrm{a}}$ & .677 & .657 & 2.584 & 1.814 \\
\hline
\end{tabular}

a. Predictors: (Constant), Budaya Tri Hita Karana, Good Corporate Governance

b. Dependent Variable: Kinerja Manajerial

Berdasarkan Tabel 3 diatas dapat diketahui koefisien korelasi berganda secara simultan besarnya $R=0,823$. Berdasarkan kreteria tinggi-rendahnya hubungan menurut Sugiyono (2004:183) koefisien korelasi (R) sebesar 0,823 di atas, terletak diantara 0,80 sampai dengan 1,000 yang berarti korelasinya sangat tinggi. Untuk mengetahui besarnya pengaruh variabel Good Corporate Governance $\left(\mathrm{X}_{1}\right)$ dan Budaya Tri Hita Karana $\left(\mathrm{X}_{2}\right)$, terhadap variable terikat kinerja Manajerial (Y) Lembaga Perkreditan Desa (LPD) Pakraman Padangsambian dapat dilihat dari nilai $R$ Square $\left(R^{2}\right)$ yaitu sebesar 0,677 . Karena besarnya $R^{2}=0,677$, maka :

$$
\begin{aligned}
\mathrm{D} & =\mathrm{R}^{2} \times 100 \% \\
& =0,677 \times 100 \% \\
& =67,7 \%
\end{aligned}
$$

Koefisien determinasi sebesar $67,7 \%$, berarti perubahan kinerja manajerial ( $\mathrm{Y}$ ) dipengaruhi Good Corporate Governance $\left(\mathrm{X}_{1}\right)$ dan Budaya Tri Hita Karana $\left(\mathrm{X}_{2}\right)$ sebesar $67,7 \%$. Sisanya sebesar $100 \%-67,7 \%=32,3 \%$ dipengaruhi oleh faktor lain yang tidak diteliti pada kesempatan ini. Pengaruh Good Corporate Governance $\left(\mathrm{X}_{1}\right)$ dan Budaya Tri Hita Karana $\left(X_{2}\right)=67,7 \%$, ini menunjukkan besarnya sumbangan Good Corporate Governance $\left(\mathrm{X}_{1}\right)$ dan Budaya Tri Hita Karana $\left(\mathrm{X}_{2}\right)$ untuk menaikkan kinerja Manajerial $(\mathrm{Y})$ Lembaga Perkreditan Desa (LPD) Pakraman Padangsambian.

\section{Hasil Uji F (F-test)}

Untuk menguji nyata tidaknya pengaruh variabel bebas Pengaruh Good Corporate Governance $\left(X_{1}\right)$ dan Budaya Tri Hita Karana $\left(X_{2}\right)$ terhadap variabel terikat kinerja Manajerial (Y) Lembaga Perkreditan Desa (LPD) Pakraman Padangsambian, maka dilakukan pengujian dengan menggunakan uji-F $\left(F_{\text {-test }}\right)$ 
Dari hasil perhitungan SPSS for Windows versi 23.0 pada Lampiran 5, dapat dibuat Tabel 4 berikut.

\section{TABEL 4 \\ Uji F}

\section{ANOVA}

\begin{tabular}{|ll|r|r|r|r|r|}
\hline Model & & \multicolumn{1}{c|}{$\begin{array}{c}\text { Sum of } \\
\text { Squares }\end{array}$} & df & Mean Square & \multicolumn{1}{c|}{ F } & Sig. \\
\hline 1 & Regression & 448.445 & 2 & 224.223 & 33.572 & $.000^{a}$ \\
& Residual & 213.726 & 32 & 6.679 & & \\
& Total & 662.171 & 34 & & & \\
\hline
\end{tabular}

a. Predictors: (Constant), Budaya Tri Hita Karana, Good Corporate Governance

b. Dependent Variable: Kinerja Manajerial

pengambilan keputusan adalah jika nilai signifikan $<0,05$ maka berarti variabel independen berpengaruh terhadap variabel dependen dan sebaliknya apabila nilai signifikan > 0,05 maka berarti variabel independen tidak berpengaruh terhadap variabel dependen.

TABEL 5

Uji t

\begin{tabular}{|c|c|c|c|c|c|c|}
\hline & & \multicolumn{5}{|c|}{ Coefficients $^{\Xi}$} \\
\hline & & \multicolumn{2}{|c|}{ Unstandardized Coefficients } & $\begin{array}{l}\text { Standardized } \\
\text { Coefficients }\end{array}$ & \multirow[b]{2}{*}{$\mathrm{t}$} & \multirow[b]{2}{*}{ Siq. } \\
\hline \multicolumn{2}{|c|}{ Madel } & $\mathrm{B}$ & Std. Error & Beta & & \\
\hline \multirow[t]{3}{*}{1} & (Constant) & -.818 & 3.978 & & -.206 & .838 \\
\hline & $\begin{array}{l}\text { Good Corporate } \\
\text { Governance }\end{array}$ & .956 & .220 & .547 & 4.340 & .000 \\
\hline & Budaya Tri Hita Karana & 1.056 & .363 & .367 & 2.908 & .007 \\
\hline
\end{tabular}

a. Dependent Variable: Kinerja Manajerial

\section{Pembahasan}

\section{Pengaruh Good Corporate Governance $\left(\mathrm{X}_{1}\right)$ secara parsial terhadap Kinerja Manajerial} (Y)

Good Corporate Governance $\left(\mathrm{X}_{1}\right)$ berpengaruh terhadap Kinerja Manajerial ( $\left.\mathrm{Y}\right)$. Dapat diketahui besarnya nilai sig untuk variabel Good Corporate Governance $\left(X_{1}\right)$ adalah $=0,000$. Apabila nilai sig $=0,000$ dibandingkan dengan nilai $\alpha=0,05$, ternyata nilai sig lebih kecil dari $\alpha=0,05,(0,000<0,05)$ dan nilai sig berada pada daerah penolakan Ho. Dengan demikian $\mathrm{H}_{\circ}$ ditolak dan $\mathrm{H}_{\mathrm{a}}$ diterima. Ini berarti bahwa secara statistik untuk uji pihak kanan pada taraf kepercayaan $(\alpha)=5 \%$, Secara parsial Good Corporate Governance $\left(X_{1}\right)$ berpengaruh positif signifikan terhadap kinerja Manajerial (Y) Lembaga Perkreditan Desa (LPD) Pakraman Padangsambian. Dengan demikian hipotesis yang menyatakan : "Ada pengaruh positif yang signifikan secara parsial Good Corporate Governance terhadap kinerja Manajerial Lembaga Perkreditan Desa (LPD) Pakraman Padangsambian" teruji kebenarannya.

\section{Pengaruh Budaya Tri Hita Karana (x2) secara parsial terhadap Kinerja Manajerial (Y)}

Budaya Tri Hita Karana $\left(\mathrm{X}_{2}\right)$ berpengaruh terhadap KInerja Manajerial $(\mathrm{Y})$. Dapat diketahui besarnya nilai sig untuk variabel Budaya Tri Hita Karana $\left(X_{2}\right)$ adalah $=0,007$. Apabila nilai sig $=0,007$ dibandingkan dengan nilai $\alpha=0,05$, ternyata nilai sig lebih kecil dari $\alpha=0,05$, $(0,007<0,05)$ dan nilai sig berada pada daerah penolakan Ho. Dengan demikian $\mathrm{H}_{\circ}$ ditolak dan $\mathrm{H}_{\mathrm{a}}$ diterima. Ini berarti bahwa secara statistik untuk uji pihak kanan pada taraf 
kepercayaan $(\alpha)=5 \%$, Secara parsial Budaya Tri Hita Karana $\left(X_{2}\right)$ berpengaruh positif signifikan terhadap kinerja Manajerial (Y) Lembaga Perkreditan Desa (LPD) Pakraman Padangsambian. Dengan demikian hipotesis yang menyatakan : "Ada pengaruh positif yang signifikan secara parsial Budaya Tri Hita Karana berpengaruh positif signifikan terhadap kinerja Manajerial Lembaga Perkreditan Desa (LPD) Pakraman Padangsambian" teruji kebenarannya.

\section{Pengaruh Good Corporate Governance (X1), Budaya Tri Hita Karana (X2) secara simultan terhadap Kinerja Manajerial $(Y)$}

Good Corporate Governance $\left(X_{1}\right)$, dan Budaya Tri Hita Karana $\left(X_{2}\right)$ berpengaruh terhadap Kinerja Manajerial $(Y)$. Ini berarti apabila Good Corporate Governance $\left(\mathrm{X}_{1}\right)$ dan Budaya Tri Hita Karana $\left(\mathrm{X}_{2}\right)$ meningkat satu satuan (satu skor), maka besarnya terikat kinerja manajerial (Y) Lembaga Perkreditan Desa (LPD) Pakraman Padangsambian dari -0,818 satuan (skor) menjadi sebesar 1,194 satuan (skor) atau kinerja manajerial $(\mathrm{Y})$ naik sebesar $=$ $1,194-0,818=0,376$ satuan (skor). Berdasarkan penjelasan di atas, secara umum dapat dinyatakan bahwa bila Good Corporate Governance $\left(\mathrm{X}_{1}\right)$ dan Budaya Tri Hita Karana $\left(\mathrm{X}_{2}\right)$ meningkat satu satuan (satu skor), secara simultan memiliki pola pengaruh positif terhadap kinerja manajerial (Y) Lembaga Perkreditan Desa (LPD) Pakraman Padangsambian. Ini menunjukkan bahwa apabila Good Corporate Governance $\left(\mathrm{X}_{1}\right)$ dan Budaya Tri Hita Karana $\left(\mathrm{X}_{2}\right)$ ditingkatkan, maka kinerja individu manajerial $(\mathrm{Y})$ akan meningkat. Sebaliknya, apabila Good Corporate Governance $\left(\mathrm{X}_{1}\right)$ dan Budaya Tri Hita Karana $\left(\mathrm{X}_{2}\right)$ berkurang, maka akan terjadi penurunan kinerja manajerial $(\mathrm{Y})$.

\section{SIMPULAN}

\section{Simpulan}

Berdasarkan hasil analisis dan pembahasan yang telah diuraikan pada bab sebelumnya dan untuk menjawab tujuan penelitian, maka dapat disimpulkan bahwa:

1. Secara parsial Good Corporate Governance $\left(X_{1}\right)$ berpengaruh positif signifikan terhadap kinerja Manajerial (Y) Lembaga Perkreditan Desa (LPD) Pakraman Padangsambian sebesar 0,609 dengan nilai sig sebesar 0,000.

2. Secara parsial Budaya Tri Hita Karana $\left(X_{3}\right)$ berpengaruh positif signifikan terhadap kinerja Manajerial (Y) Lembaga Perkreditan Desa (LPD) Pakraman Padangsambian sebesar 0,328 dengan nilai sig sebesar 0,007 .

3. Secara simultan (bersama-sama) pengaruh yang terdiri atas atas Good Corporate Governance $\left(X_{1}\right)$ dan Budaya Tri Hita Karana $\left(X_{2}\right)$ memiliki pengaruh positif yang signifikan (nyata) terhadap variable terikat kinerja Manajerial (Y) Lembaga Perkreditan Desa (LPD) Pakraman Padangsambian sebesar 67,7\%, pengaruh positif artinya Good Corporate Governance dan Budaya Tri Hita Karana telah tebukti atau mampu memberikan peningkatan kinerja Manajerial (Y) Lembaga Perkreditan Desa (LPD) Pakraman Padangsambian. Dari kedua variabel bebas yaitu Good Corporate Governance $\left(\mathrm{X}_{1}\right)$ dan Budaya Tri Hita Karana $\left(\mathrm{X}_{2}\right)$ yang paling dominan mempengaruhi kinerja Manajerial $(Y)$ Lembaga Perkreditan Desa (LPD) Pakraman Padangsambian adalah variabel Good Corporate Governance $\left(\mathrm{X}_{1}\right)$.

\section{Saran}

Sehubungan dengan hasil yang diperoleh dari penelitian ini dapat disampaikan beberapa saran sebagai bahan pertimbangan kepada pimpinan Lembaga Perkreditan Desa (LPD) Pakraman Padangsambian yaitu :

1. Mengacu pada kesimpulan di depan yang menyatakan, variabel bebas penelitian yang meliputi Good Corporate Governance .dan Budaya Tri Hita Karana terhadap kinerja Manajerial Lembaga Perkreditan Desa (LPD) Pakraman Padangsambian, maka pimpinan di LPD Desa Adat Padangsambian perlu tetap menjalankan 
kebijakan yang berkaitan dengan variabel di atas secara bersama-sama, bila perlu lebih ditingkatkan.

2. Dari kajian secara parsial, hendaknya pihak pimpinan tetap mempertahankan dan memperhatikan disiplin kerja. Variabel Good Corporate Governance memiliki pengaruh positip yang paling dominan terhadap kinerja Manajerial Lembaga Perkreditan Desa (LPD) Pakraman Padangsambian, selanjutnya disusul dengan variabel Budaya Tri Hita Karana agar kinerja Manajerial Lembaga Perkreditan Desa (LPD) Pakraman Padangsambian tetap optimal atau maksimal sesuai dengan harapan dari manajemen LPD Desa Adat Padangsambian.

\section{REFERENSI}

Adiputra, I. Made Pradana. 2014. Budaya Tri Hita Karana Sebagai Pemoderasi Pengaruh Kompleksitas Tugas Terhadap Kinerja Internal Auditor (Studi Pada Kantor Inspektorat di Provinsi Bali). Jurnal Dinamika Akuntansi, 6(2), h: 191-206.

Aldridge, John.E, dan Siswanto Sutojo. 2015. Good Corporate Governance. Jakarta: PT. Damar Mulia Pustaka.

Alfar, R. 2006. Pengaruh Partisipasi Manajer dalam Penganggaran terhadap Kinerja Manajerial dengan Budgetary Slack sebagai Variabel Intervening.Tesis.Sekolah Pascasarjana USU. Medan.

Anantawikrama, Tungga Atmadja. 2013. LPD as the Embodiment of Financial Institutions Based on Social Capital in Bali, Indonesia. Journal of Integrative Business \&Economics Research, Ganesha University of Education. Rev.Intergr.Bus.Econ.Res. Vol 2 (2)

A.Prasetyantoko. 2008. Coporate Governance: Pendekatan Institusional, Gramedia, Jakarta. Arfan, Ikhsan dan Muhammad Ishak, 2005, Akuntansi Keprilakuan, Salemba Empat, Jakarta.

Argyris. 1952. Organizational Leadership dan Participation management. The Journal of Business. Vol. XXVII (January): 1-7

Arya, Wirama dan Badera. 2017. Budaya Tri Hita Karana Sebagai Pemoderasi Pengaruh Prinsip Good Corporate Governance Pada Kinerja Lembaga Perkreditan Desa Di Kota Denpasar. E-Jurnal Ekonomi dan Bisnis Universitas Udayana 6.8 (2017)

Asri, Ulupui dan Wirawati. 2017. Pengaruh Good Corporate Governance Dan Budaya Tri Hita Karana Pada Kinerja Bank Perkreditan Rakyat. Jurnal Ilmiah Akuntansi dan Bisnis, Vol. 12, No. 1. Fakultas Ekonomi dan Bisnis, Universitas Udayana

Barnhart, Scott W. Dan Stuart Rosenstein. 1998. Board composition, managerial ownership, and firm performance: An empirical analysis.

Bhaskara dan Erawati. 2017. Pengaruh Penerapan Prinsip-Prinsip Good Corporate Governance Dan Budaya Tri Hita Karana Pada Kinerja Keuangan. E-Jurnal Akuntansi Universitas Udayana Vol.19.1

Brownell .P. 1982. Participation in budgeting Process: When It Works andlit Don't, Journal of Accounting Literature, Vol. 1: 124-153

Damayanthi Eka. 2015. Pengungkapan Tanggung Jawab Sosial Lembaga Perkreditan Desa (LPD) Berdasarkan filosifi Tri Hlta Karana.Artikel Seminar Hasil Penelitian Fakultas Ekonomi Universitas Udayana.

Ghozali, Imam. 2011. "Aplikasi Analisis Multivariate Dengan Program SPSS". Semarang: Badan Penerbit Universitas Diponegoro.

Ghozali, Iman. 2012. Aplikasi Analisis Multivariate dengan Program IBM SPSS 20. Semarang. Badan Penerbit-Universitas Diponegoro.

Ghozali, Imam. 2013. Aplikasi Analisis Multivariate dengan Program SPSS. Edisi Ketujuh. Semarang : Badan Penerbit Universitas Diponegoro.

Ghozali, Imam. 2015. Aplikasi Analisis Multivariate dengan Program IBM SPSS 23.Semarang : Badan Penerbit Universitas Diponegoro.

Gunawan, K. 2009. Pengaruh Budaya Organisasi, Kepuasan Kerja dan Motivasi Kerja terhadap Gaya Kepemimpinan dan Kinerja Organisasi (Studi pada Lembaga Perkreditan Desa (LPD) di Bali). Disertasi. Universitas Brawijaya. 
Gunawan, Ketut. 2012. Peran Falsafah Tri Hita Karana bagi Pertumbuhan dan Kinerja Lembaga Perkreditan Desa (LPD) di Bali. Jurnal Analisis Manajemen,5(2), h: 23-36.

Koentjaraningrat. 1993. Metode-metode Penelitian Masyarakat. PT. Gramedia Pustaka Utama. Jakarta.

Komite Nasional Kebijakan Governance, Pedoman umum Good Corporate Governance, Indonesia, Jakarta, 2006

Mahoney.et al. 1963. Development of Managerial Performance: A Research Approach. Cincinnati: South Western Publishing.

Merchant, Kenneth A. 1981. The Design of the Corporate Budgeting System : Influences on Managerial Behavior and Performance, The Accounting Review, Vol. LVI, No.4.

Moh. Wahyudin Zarkasyi. 2008. Good Corporate Governance Pada Badan Usaha Manufaktur, Perbankan, dan Jasa Keuangan Lainnya. Bandung: Alfabeta.

Oliver Hart. 1995. Corporate Governance: Some Theory and Implications. The Economic Journal, 105(430), pp: 678-689.

Riana, I Gede. 2010. Dampak Penerapan Budaya Tri Hita Karana terhadap Orientasi Kewirausahaan dan Orientasi Pasar serta Konsekwensinya pada Kinerja Usaha dengan Moderator Pembelajaran Bisnis.Disertasi. PDIM UB.

Ridwan Khirandy dan Camelia Malik. 2007. Good Corporate Governance Perkembangan Pemikiran dan Implementasinya di Indonesia dalam Perspektif Hukum, Total Media, Yogyakarta.

Saputra, Komang Adi Kurniawan. 2012. Pengaruh Locus Of Control Terhadap Kinerja dan Kepuasan Kerja Internal Auditor dengan Kultur Tri Hita Karana sebagai Variabel Moderasi. Jurnal Akuntansi Multiparadigma, 3(1), h: 86100.

Sedarmayanti. 2004. Good Governance (Kepemerintahan Yang Baik), Mandar Maju, Bandung.

Shu-Mei Tseng. 2010. The Correlation Between Organizational Culture and Knowledge Conversion on Corporate Performance. Journal of Knowledge Management, 14(2), pp: 269-284

Siregar, Syofian. 2013. Metode Penelitian Kuantitatif. Jakarta: PT Fajar Interpratama Mandiri.

Stoner, Freeman. 1992. Manajemen Edisi Keempat. Jilid I. Alih bahasa Benyamin Molan, Intermedia.

Supomo dan Indriantoro.1998.Pengaruh Struktur dan Kultur Organisasi terhadap Keefektifan Anggaran Partisipatif dalam Peningkatan Kinerja Manajerial.Kelola Vol. VII No. 18.Maret.

Sugiyono. 2011. Metode Penelitian Pendidikan (Pendekatan Kuantitatif, Kualitatif, dan R\&D). Bandung. Alfabeta

Sugiyono. 2014. Metode Penelitian Kuantitatif, Kualitatif, dan R\&D. Bandung: Penerbit Alfabeta.

Sugiyono. 2015. Metode Penelitian Pendidikan (Pendekatan Kuantitatif, Kualitatif dan R\&D). Penerbit CV. Alfabeta: Bandung.

Sukandia, I Nyoman.Nurjaya, I Nyoman \& Eka Wijaya W, I Dewa Putu. 2011. Landasan Teoritik Pengaturan LPD Sebagai Lembaga Keuangan Komunitas Masyarakat Hukum Adat di Bali. Diterbitkan oleh Udayana University Press.

Sutoro, Eko. 2015. Regulasi Baru, Desa Baru: Ide, Misi dan Semangat UU Desa. Cetakan Pertama, Maret 2015.Diterbitkan oleh Kementerian Desa, Pembangunan Daerah Tertinggal dan Transmigrasi Republik Indonesia.Jl. Abdul Muis No. 7 Jakarta Pusat 10110.

Vita Indriyani Ni Made. 2018. Pengaruh Good Corporate Governance Dan Budaya Tri Hita Karana Pada Kualitas Laporan Keuangan. Tesis Program Magister Akuntansi Fakultas Ekonomi Dan Bisnis Universitas Udayana.

Wasisto, Arif \& MAU Sholihin. 2004. Peran Partisipasi Penganggaran dalam Hubungan Antara Keadilan Prosedur dengan Kinerja Manajerial dan Kepuasan.Simposium Nasional Akuntansi VII Denpasar.

Windia, W. dan Dewi, R. K. 2007.Analisis Bisnis yang Berlandaskan Tri Hita Karana. Denpasar: Universitas Udayana. 
Yudana, P. I., Cipta, W., dan Suwendra, I W. 2015 Pengaruh Kredit Bermasalah dan Perputaran Kas terhadap Likuiditas pada Lembaga Perkreditan Desa Kecamatan Seririt.E-journal Bisma Universitas Pendidikan Ganesha, 3 (tanpa halaman).

Yulia Fitri. 2004. Pengaruh Informasi Asimetri, Partisipasi Penganggaran, dan Komitmen Organisasi terhadap Timbulnya Senjangan Anggaran (Studi Empiris pada Universitas Swasta di Kota Bandung). Makalah disampaikan pada Simposium Nasional Akuntansi (SNA) VII. Denpasar Bali, 2-3 Desember. 